Témoigner Témoigner. Entre histoire et mémoire

Getuigen Revue pluridisciplinaire de la Fondation Auschwitz

$119 \mid 2014$

II y a 70 ans, Auschwitz. Retour sur Primo Levi

\title{
Between testimony and memory, what place for Primo Levi?
}

Entre témoignage et mémoire, quelle place pour Primo Levi?

Tussen getuigenis en herinnering: waar plaatsen we Primo Levi?

\section{Philippe Mesnard}

\section{(2) OpenEdition}

Electronic version

URL: http://journals.openedition.org/temoigner/1506

DOI: 10.4000/temoigner.1506

ISSN: 2506-6390

Publisher:

Éditions du Centre d'études et de documentation Mémoire d'Auschwitz, Éditions Kimé

Printed version

Date of publication: 31 December 2014

Number of pages: $78-92$

ISBN: 978-2-84174-688-0

ISSN: 2031-4183

\section{Electronic reference}

Philippe Mesnard, «Between testimony and memory, what place for Primo Levi? », Témoigner. Entre histoire et mémoire [Online], 119 | 2014, Online since 01 June 2015, connection on 23 October 2020. URL : http://journals.openedition.org/temoigner/1506 ; DOI : https://doi.org/10.4000/temoigner.1506 


\section{Between testimony and memory, what place for Primo Levi?}

$\rightarrow$ Philippe Mesnard

M emory today, as we have understood it for some time, has something of a defect, a construction defect, if I may say so. It examines from all angles the depths and perspectives as if it held the answer to everything which preoccupies us about the past, depending on its own categories and the values it confers. Thus, a witness would always have been a witness, as soon as he began writing about the experience for which he will be famous. In the same way, he can only contribute to this vast and worthy collective memory enterprise, without imagining he could become tired of the duty of remembrance, or critique it. Yet, this is what a close reading reveals about Primo Levi, considered one of the most "classic" witnesses of his time, as well as a sense of ambivalence. For this, suffice to consider the writing conditions and the circumstances of the various versions of If This Is a Man, as well as the testimonial fatigue he felt from the end of the 1970s. But first, let us briefly describe the post-war context and the ambience in which Primo Levi evolved after returning from Auschwitz.

\section{WHICH COMMUNITIES?}

After twenty-four years of a Fascist regime and a consenting majority, the postwar period in Italy became a theatre where anti-Fascist figures and their martyrs fallen with "arms held high" were held in great esteem. Amongst the ruin, heroic and redeeming figures were highly acclaimed especially as the political and social climate was extremely troubled. On the one hand, Fascism still held a presence, whether in public administrations which had remained sheltered from the purge (see Pavone 1995), or as a political pressure group, practically still militarized, a sign of the unsevered roots with the previous regime. On the other hand, the Communist Party tried to profit from the situation to establish a monopoly over the regions. In the face of this, the Christian Democracy did not hesitate to pass alliance with postwar Fascists. Government instances tried to avoid the heavy question of anti-Semitic persecutions by making Nazis carry the entire responsibility (Bertilotti 2009, 384). Thus, the myth of a Fascist Italy, though not anti-Semitic, and the idea of a brava gente Italian enhanced the national image beyond the borders, whereas inside them, reigned a climate of latent civil war. Along with its cortege of elimination and purges 


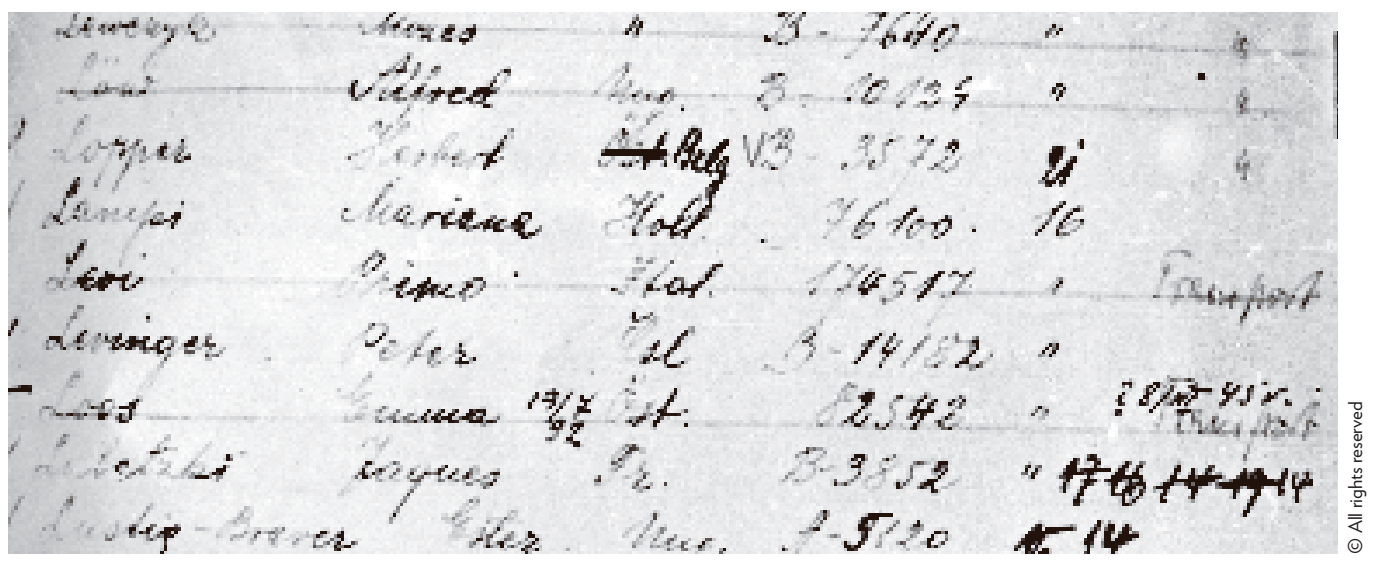

(Crainz 2009), this carried on until the beginning of the 1950s, like in most Eastern European countries as well (Low 2012).

What place did the Jewish survivors, who had not or only rarely taken part in the Resistance, then hope for? What recognition was there for their fate, humiliated and banished from Mussolinian society until September 1943, to then be persecuted and deported to be killed? Contrary to the sufficiently promoted platitude still upheld by a few historians today, they were not rejected nor silenced, but welcomed with "the means available", whereas the national ship continued to take water, and the course of its trajectory remained uncertain.

As was generally the case, associations became the first real actors of memory. The Associazione nazionale ex-deportati politici in Germania - ex-zebrati dei campi di eliminazione (ANED) was created on 6 September 1945. It became a real refuge for the survivors and families of the disappeared. Research was undertaken to establish the number of deportees and the places of deportation. In 1947, eighteen sections were active within the country. Other associations were equally active, some joined the ANED, others turned away from it for questions of political obedience, for it was, indeed, close to the Communist Party. Same as in France or in Belgium, these associations of ex-deportees together formed a phenomenon we could call a memorial community. They organized commemorations, exhibitions and important events such as the transfer of the unknown deportee from Mauthausen to the cemetery in Turin in 1948, and the erection of a monument to the Deportee in the main cemetery in Milan. Primo Levi returned to Turin on 19 October 1945 and immediately became a frequent visitor of the ANED. He attended the events they organized and entertained warm relations with its members. The leaders had all been involved in the Resistance, most of them at a high level. In 1948, the ANED was officially recognized as a moral authority. The memorial community, through its most active associations, struggled for the recognition of deportees and the attribution of a clearly defined status. It was defined by its political colour to the point that we can claim that the 
Between testimony and memory, what place for Primo Levi? (continuation)
(1) "Seelische und emotionale Gemeinschaft" (Kertész 1999, 56) memorial construction was one of the aspects of political struggle which carried on during the post-war period.

The testimonial community did not raise such issues, shaped by the often tacit or at least nonconcerted convergence of testimonies on the same lived and shared history. Referring to an informal reality, the expression "testimonial community" remained very metaphorical. We could associate it to what Imre Kertész called a community stripped of its destiny, hence a reference to the title of his work on his own deportation, a "spiritual and emotional" community, or to Maurice Blanchot's "workless community". This community was not only made up of survivors, but also of the disappeared, for whom there was no way of knowing what had happened to them and the dead who perpetually haunted the mental universe of those who had escaped the Nazi terror. Relations developed, non-instituted networks formed in parallel to the associations hoping to discover if such a person had survived, if there was any news of such a person, if another person had in fact died at such a place. This community came together discreetly with, as sole framework and point of reference, each others' addresses and their occasionally tenuous relations with associations. Even though both testimonial and memorial communities intercrossed, they did not however overlap.

On the other hand, although discrete, Jewish associations were also active. On 26 September 1944, the Union of Jewish Italian Communities created a Search Committee for Deported Jews (CRDE). We are still far, at this point, from a clear recognition of the specificity of the Shoah and far from looking straight at the overwhelming responsibilities of the Mussolinian regime within anti-Semitic politics leading to genocidal deportations. It is however easy to consider that the terror which struck anti-Fascists differed from the Jewish "scramble" which was given free reign under the Republic of Salò, from September 1943 onward. Both persecutions did not answer to the same objectives nor ideological foundations. In spite of this, the initiative of the CRDE at that time limited its activities to drawing the census of missing people and joined in the commemorative initiatives of the resistant associations in which Jewish victims came together. It also attempted to control the flow of Jews who, chased by the violence and instability of the East after the war, wished to reach Israel. Primo Levi namely mentioned some of them in The Truce, he also imagined the story at the end of his novel If Not Now, When?. If he found himself belonging to these three entities, participating in them, the fact remained that he adopted a unique position when he began to transcribe his concentration camp experience.

\section{WHICH WRITINGS?}

During the first year after his return, Levi was not yet a witness in the sense we understand today. To consider him as such would even be an abusive reconstruction interfering in the understanding of the complex process of his becoming a "witness" (but can it be otherwise for anyone who has returned from such an experience?). After several difficult months, he managed to recover a balance both on a profes- 
sional and emotional level. He quickly found work as a chemist at Avigliana, not far from Turin, and met Lucia Morpugo at the beginning of 1946. They married a year later. The uniqueness of his journey as a survivor is not so much due to what he wrote - many people chose to write -, but to the fact that his writing was part of a vast and varied movement, both a writing project and an experience as such. We can thus affirm that Levi was a writer before being a witness. A writer who did not belong to a literary field, who in fact kept himself at a distance from such fields, all the while hoping for recognition. This movement animated him and took up all his free time (lunch breaks during working hours as well as evenings), jotting down notes, transforming them into fiction. His drive cannot solely be understood as a testimonial impulse, it cannot either be explained as mere psychological reconstitution or retrieval. Writing, transcending the question of self, is not so easily delimited. His extreme diversity, reflecting in part the complexity of his own personality, expressed his desire to create an inner scene where the echoes of his own ghosts were able to play out and express themselves, whilst opening himself to the world of his readers, for Primo Levi's writing always remained highly transitive. During his lifetime he wrote several texts with radically differing writing styles and genres at the same time. During the first years after his return, he produced poetry, a documentary text, strictly inventive fiction in the form of short stories and short forms which, like paintings, retraced his deportation and his concentration camp experience. ${ }^{2}$ I shall try to show how this context set the necessary conditions for If This Is a Man, which at the time did not fit into any specific genre. It also bore another title altogether, its definitive one was imposed at the time of the first publication of the book by Levi's editor who borrowed it from one of his poems, written when he had returned from deportation.

Representative of such plurality, poetry was for him an essential expression, always harbouring worry and pain (of lost persons, of having experienced persecutions, genocide, concentration camps - of the violence). "The poems came to me first, I had just returned to Italy”, he later confided (Levi 1998, 138). Indeed, after his return he wrote fifteen poems until 1946 when his writing took a new direction. At the beginning of this year he met Lucia Morpugo and felt himself ease back to a happiness of life and was once again filled with love. On the other hand, his writing with Leonardo De Benedetti precisely contained both testimonial value and intention. They published in the July-December 1946 edition of the Minerva Medica review a supplemented version of the report which the Red Army had commissioned them to do while they were at the Katowice camp in 1945, immediately after their release from Auschwitz and before their epic return (Levi 2006). The report is written in a clear and concise style and its literary worth surpasses its strictly documentary value. If De Benedetti contributed to the project with his diagnosis, Levi uplifted it with his style. It contained the real key elements elements of If It Is a Man. A significant progression marks the passage from the first version, an expertise addressed to military men seeking proof, to the second version, destined to Italian readers who ignored all that had happened on the other side of Europe. This first rewriting bore

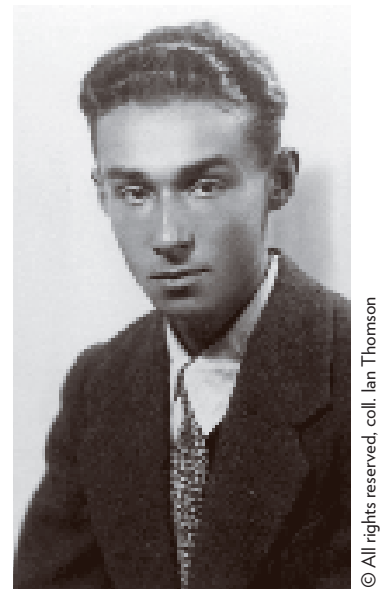

- Primo Levi

as a student, around 1938.

(2) Thereafter, theatre, novels, essays, journalistic and intellectual chronicles expanded the diversity of his work. 
Between testimony and memory, what place for Primo Levi? (continuation) the question of a testimonial address and, thereby, of the future project of a survivor who later became one of the most famous witnesses of Nazi concentration camps and the genocide of the Jews.

This exercise, both documentary and testimonial, was synchronous to the writing of the book to come, If This Is a Man, far from expecting what would come of it. Furthermore, a certain number of pages about the end of his detention only found their place in The Truce, fifteen years later. Levi wrote most of the episodes of his deportation and internment at his workplace, at Avigliana. But he did so in reverse, so to speak. Mid-February 1946, he began writing the final chapter that would later become "The Story of Ten Days". At the end of December of the same year, he completed what then more closely resembled a collection of paintings or episodes than a story. The chronological succession was not always a relevant entry to determine the content and the meaning.

There is a chapter I wish to pause on, because, though it has rarely been the object of reflection, its genesis contains a fundamental lesson of testimony according to Levi, at a time when this expression and the transmission of his experience had not yet reached its full potential. I am referring to chapter sixteen, "The Last One", which is in fact the penultimate chapter of the book. Levi sketched a draft of it during March and April 1946. In order to grasp the entirety of its extent, it is important to place it in relation to the fictional short stories Levi gathered into several volumes, which until recently has been little commented on. We shall here focus on the text titled with the beautiful neologism "The mnemagogue" (Il mnemagogo).

To begin, what can be said about the "Last One"? On 7 October 1944, the final Jewish revolt within the death camps burst at Birkenau, led by the Sonderkommandos. It mainly had a symbolic impact for it did not receive any support from the highly organized network of Communist resistance who, like in the other camps, focused on preparing the post-war period and guarantying the survival of its own members. This revolt benefited from several accomplices, amongst others, from within the Monowitz camp, most of whom were identified by the Gestapo and executed. This is what Primo Levi dramatized in the penultimate chapter. Hangings were one of the most recurring elements in testimonies of Nazi camps. Sentences were given for attempting to flee, or breaking SS rules, for example, homosexuality or a trafficking in which the SS did not gain anything. Levi describes the execution of a member of the Resistance entangled in this revolt project, as well as its theatrical quality: the convicted person stands at the gallows with thousands of deportees aligned in front of him, at the Appelplatz. Before the sentence is carried out, the man addresses the crowd, assigned to the obscene position of a spectator: Kamaraden, Ich bin der Letzte (Friends, I am the last one).

I wish I could say that from the midst of us, an abject flock, a voice rose, a murmur, a sign of assent. But nothing happened. We remained standing, bent and gray, our heads dropped, and we did not uncover our heads until the German ordered us to do so. The trap-door opened... (Levi 1959, 177) 


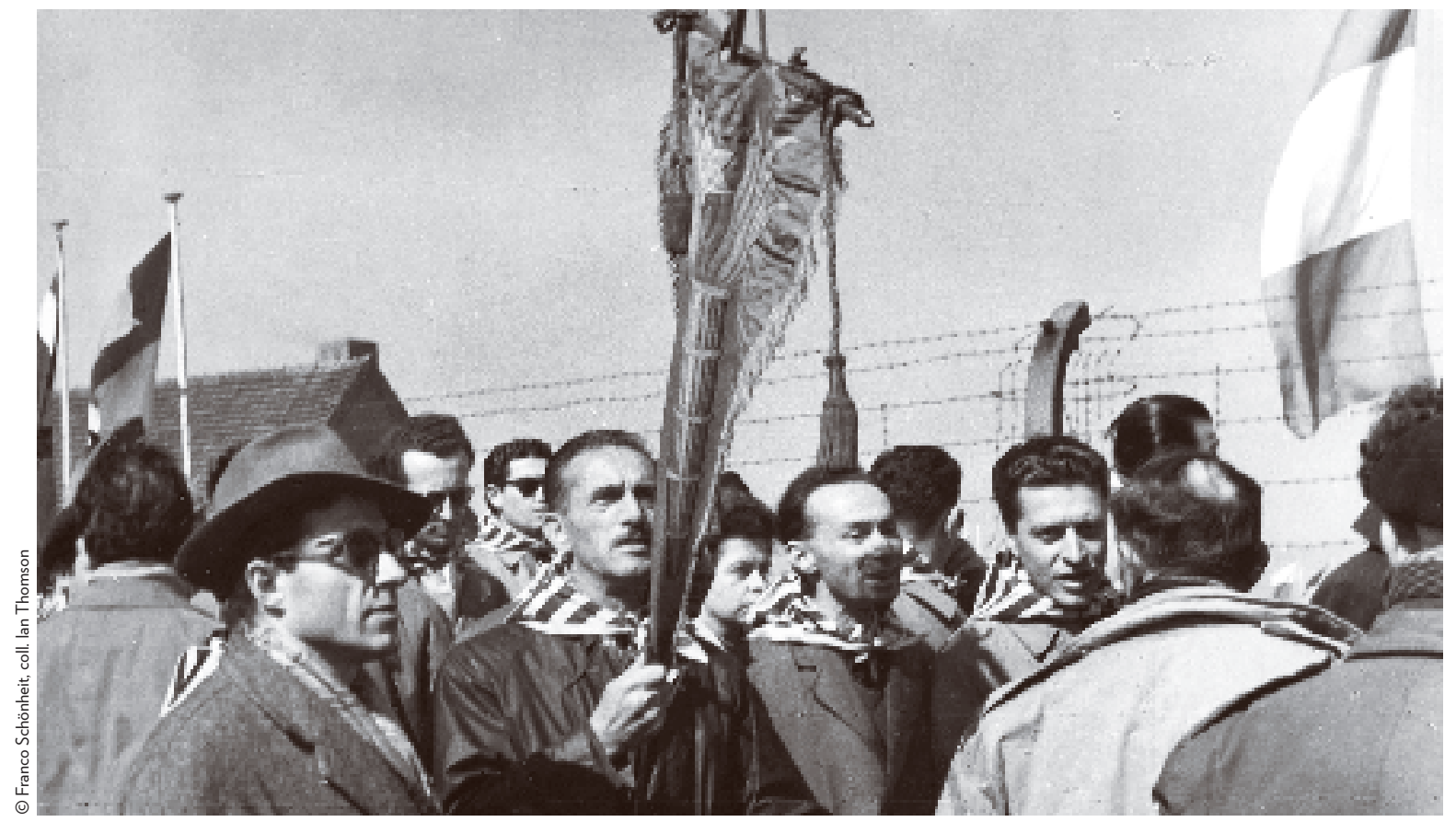

This is one of the rare passages of the story, as well as in later texts, where Levi directly addressed the question of physical violence and killing, as if repulsed from having to deal with the question of this kind of representation. The most surprising fact however is that the scene is entirely recreated. In 1946, there were indeed three detainees rather than just one, three "prisoners, accused of having tried to plan [literally, to promote] a simultaneous insurrection [to the one by the Sonderkommandos] at the Monowitz Lager"3. We learned in a letter dated from 17 October 1965, written by Guiliana Tedeschi and co-signed by Levi and De Benedetti, that Primo Levi witnessed this hanging with De Benedetti.

A scene with all three detainees did not satisfy the idea of transmitting exemplary events. Overly faithfully transcribed facts risked interfering with the understanding desired by the author. In a country as catholic as Italy, the image of a crucifixion within such a context of suffering would have been too easily solicited and would have betrayed the real event. Levi therefore recreated the scene in order to better highlight, on the one hand, the resistance which man's humanity is dependent on, and on the other hand, the deportees' most accomplished debasement which the system, according to him, seemingly managed to reject beyond humanity. The only one who still belongs to humanity is the hanged person. An implacable observation which most commentaries later shed light on.

_ Primo Levi at the

Buchenwald memorial, April 1954.

(3) See the Primo Levi collection, Wiener Library, London, NB 257, box 1406/2. 


\section{DOSSIER}

Between testimony and memory, what place for Primo Levi? (continuation)

(4) Interviews with Jean Samuel in 2006.

- 27 September 1963. First television show with Primo Levi on RAI.
At the basis of the writing of these first pages lies an ethics of testimony and communication, which requires being more faithful to the value than to the reality of facts. This ethics is confirmed by the way in which Levi also recreated the highly commented famous passage of "the Canto of Ulysses". Jean Samuel confirmed that both himself and Levi did not live the situation as the story describes it. ${ }^{4}$ Thus, not only did Levi prove to be a writer by becoming and to become a witness, but the fundamental elements of an ethics, which attempted to measure the extreme violence contemporary to the subject, is affirmed before being properly recognized as a testimony. Without knowing it, Levi followed a Levinassian logic.

Let us now turn to the short story titled "The Mnemagogue”, which responds to the specifically literary genre of science fiction and can also be read independently from all reference to the universe of concentration camps. "- Have you never noticed with what force certain smells evoke certain memories?”, asks the scholar, the protagonist of the story. Smell is a sense deeply marked by experience for at least two categories of beings which Levi both belonged to. The figure of the chemist, especially as he made paints and varnishes same as Levi did until he retired, and the deportee who was steeped in the pungent smell of human bodies burning continuously in the crematoriums, as well as the smells of bodies transformed into vermin by the insalubrity in the concentration camp. Acting independently from any sense of will,

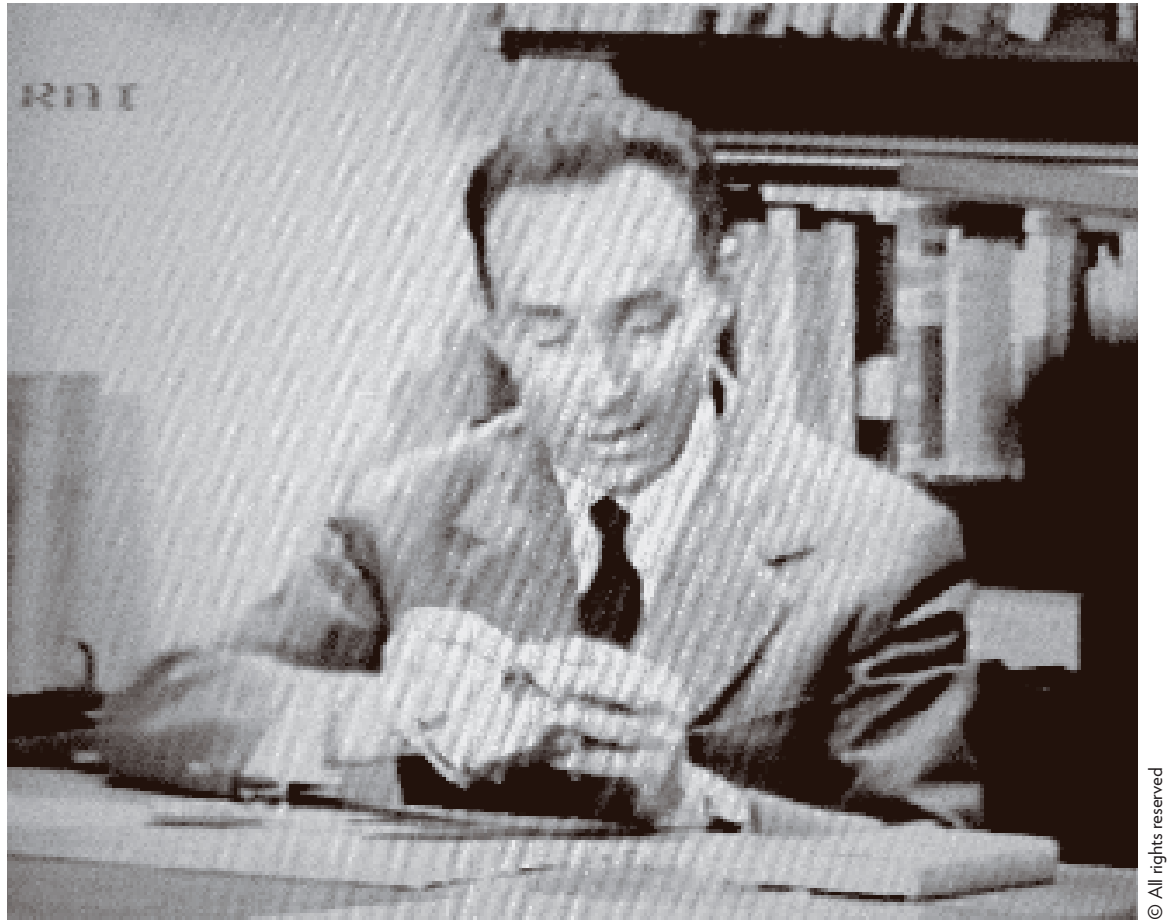


smells reveal to be a terrible trigger of memory. It is therefore not a coincidence if Levi's first completed short story was dedicated to the memory of smells, whilst in parallel he continued disparately writing chapters of Se questo è un uomo. According to the scholar of the "Mnemagogue", who confides in his interlocutor:

[...] there are people who are not concerned with the past, who let the dead bury their dead. There are others, on the contrary, who are preoccupied with the past and for whom its continual vanishing saddens. There are still others who take time to keep a journal, day after day, so that every detail about them may be saved from being forgotten, and who keep in their homes or on themselves materialized memories: a dedication in a book, a dried flower, a ringlet of hair, photographs and old letters.

By nature, it is only with horror that I consider the eventuality that even one of my memories must disappear, and I have adopted all these means, but I have also invented a new method. ${ }^{5}$

The aforementioned "method" is of course what he calls that of "mnemagogues: 'arousers' of memories" (Ibid.). Along with what is mentioned in the short story: the siliceous smell of mountain stones - Levi is an experienced climber of the Alpine summits -, the smell of dusty classrooms or the delicate sensitivity of "clean skin, rice powder and summer" (Levi 1994, 20), the joyous world from before the war is revived, filled with the overly legendary gentleness that memory attaches to worlds from before the disaster. The alchemy of involuntary memory helped him find a distance which could not only come from writing his experience, which bore too much death and corruption. At the same time as he transcribed and shaped what he had lived at Auschwitz, Levi resorted to literature as a way of finding meaning through invention. He escaped from the camp in order to come back to it with greater precision. He wrote his detention by following the rules of voluntary memory: a rational exercise, totally in line with the heuristic approach of a chemist, a method which allowed him to demarcate the paths of his own past as he clambered back up them - this clearly explains why Levi wrote If This Is a Man by starting with the end. Furthermore, the voluntary quality of such a memory, which presupposes that a subject - positioning himself self-prophetically as such - is certainly determining in the creation of exemplary models and scenes as the chapters titled "The Last One" and "The Canto of Ulysses". In other words, there is a logical link between will and exemplarity regarding the relation this memory establishes between past and transmission.

But Levi knew that this memory merely represented a pan of what it takes to make the past come back to someone. If mnemagogues etymologically are guides, this is independently from the will of the subject they act upon. In Wor the Memory of Childhood, Perec set up a fictional stage to project that which, from his lived experiences, remained buried in arcana, and in the face of which biographic intentionality remains without any means. In the same way, Levi opened up a science-fictional space in order to, within the framework of science with which he is familiar, express
(5) "Il Mnemagogo" appears in Storie naturali (1966) but was not included in the English volume The Sixth Day (1990). We translate from the French here (Levi 1994, 16). (SV) 
Between testimony and memory, what place for Primo Levi? (continuation)
(6) Storie Naturali and Vizio di forma are part of the same volume in the English edition, The Sixth Day (Levi 1990). the immemorial power of involuntary memory. It is capable of making entire worlds appear from the limbo of things forgotten where they had remained buried, just as Proust so remarkably mentioned and taught.

The narrative of olfactory reminiscence highlights how certain activities of memory, even undertaken by a former deportee, must be distinguished from memory in the social and collective sense of the term, with its public obligations and duties such as Levi only began to accept roughly ten years afterward. When he initially wrote his first short story, extensively lengthy and later resulting in two books, ${ }^{6}$ he did not think about publishing them and held onto them as so he did with many other projects. Writing these lines helped him to return among the living and, thus, quietened the ghosts which haunted the survivor - this would be like the noble task of a modern Orpheus, who is a witness, a man revived to himself, what Jean Cayrol certainly named the "Lazarus" writer (Cayrol 1950).

In this sense, is it not a way of missing what testimonies mean and mean to $u s$ than to consider it in isolation from a system of plural writing, or even plural expression, as well as from the tensions between voluntary and involuntary memories through which it is realized and takes on meaning for the person who resorts to it - and for those who discover it? This is what Primo Levi's writing reveals from this latency period, spreading from the end of 1945 until 1947, until the publication of his first version of If This Is a man. As soon as texts enter a phase of publication, as soon as they open up to the public domain, their meaning changes. It was completely possible at the time for If This Is a Man to become a testimonial narrative, though by inference, whereas Primo Levi was heading toward his well-known position as a witness, in which he also ended up feeling confined.

\section{TESTIMONIAL RECOGNITION AND REWRITINGS}

The way in which the various prepublications of If This Is a Man were organized, through periodicals, from the very Communist Amico del popolo at Vercelli, printed at 10,000 copies, to the very intellectual Il Ponte at Florence, finishing with the publication of the book on 11 October 1947 at De Silva, echoes our preliminary contextualization. Indeed, Levi the survivor and budding public witness stood apart from Levi the writer, closer to Levi the chemist with whom he shared his professional time by carving out breaks and intervals. At the occasion of the tenth anniversary of the end of the war, Primo Levi's testimonial destiny was materialized.

In Italy at the beginning of the 1950s, testimonial or fictional works related to Nazi persecutions became more easily received. Anne Frank's Journal was published in 1954. Les Armes de la nuit by Vercors and David Rousset's two books were also published, as well as Der Totenwald in which writer Ernst Wiechert, an opponent of Nazism, tells the story of his internment at Buchenwald in 1938. L'Espèce humaine (The Human Race) by Robert Antelme, a close relation of Elio Vittorini, found its place within Einaudi's catalogue. Still in 1954, Si fa presto a dire fame by Piero Caleffi, deported to Mauthausen, inaugurated the resurgence of Italian testimonies, which 
were still slow to be published. The resistant, partisan, antifascist, democratic or Communist Italy prepared to celebrate the ten years of the victory, which certain associations precisely saw as an opportunity to make their historical and political importance recognized nationally. This key moment in post-war Italy was also key for Levi who, in 1955, took for the first time the position of a public witness and, the same year, signed a contract for If This Is a Man to be republished by the prestigious Einaudi.

The ANED, at the time loosing its momentum, chose this favourable period to throw a vast itinerant photography exhibition, the Mostra della Resistenza in Piemonte. It aimed to make the association known to the general public and to spread its sphere of influence, thus becoming the keystone of a real memory policy. Levi took advantage of the inauguration in Turin on 28 May 1955, at the Palazzo Madame, to put in a public appearance and, thereby, to commit himself openly by penning a text "Deportees. Anniversary" (Deportati Anniversario) in the April edition of Torino, a monthly review the city distributed for free. $\mathrm{He}$ expressed therein his fears that memory of the genocidal violence in the concentration camps may be slipping away. "Ten years on from the liberation of the concentration camps, it is both distressing and deeply indicative to note that

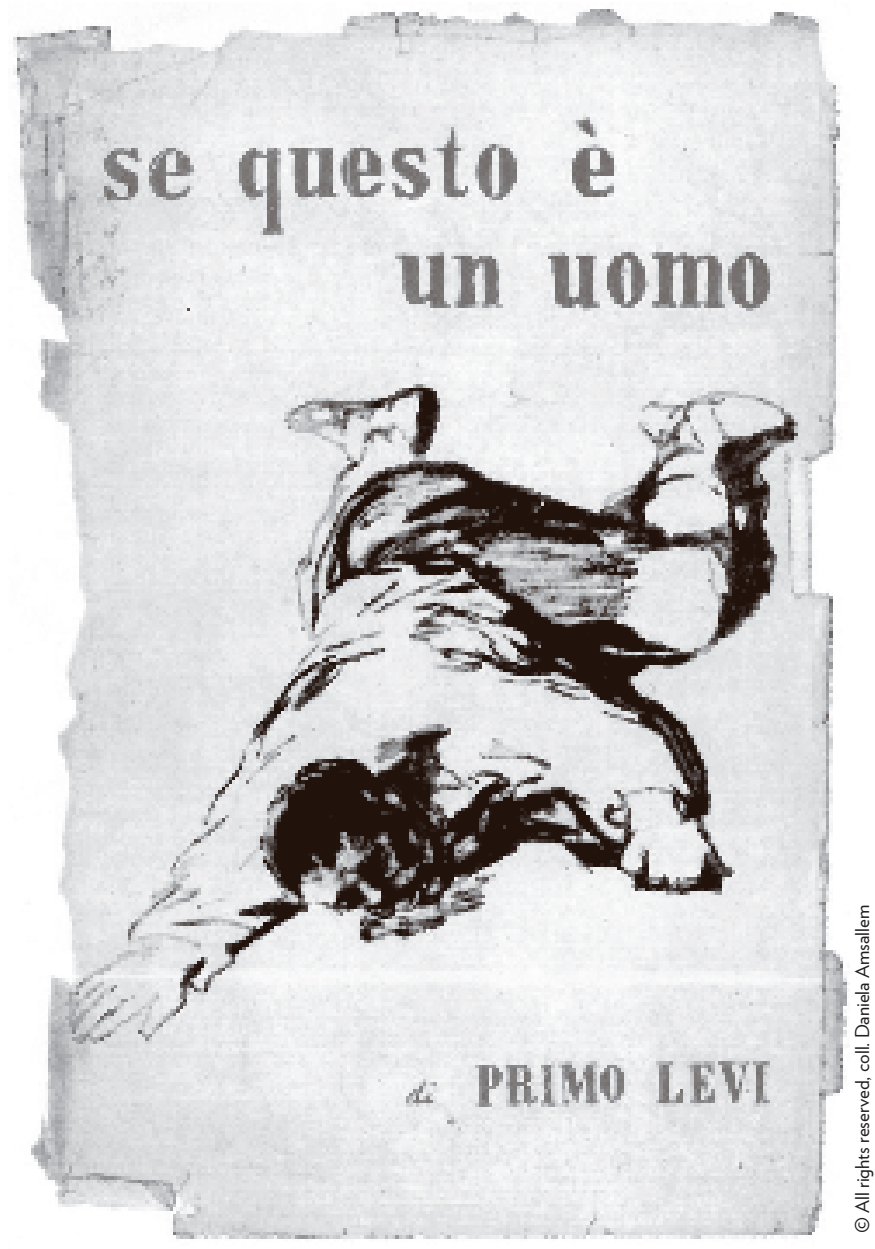
in Italy at least, far from being an important part of our history, the subject of the extermination camps is in the process of being completely forgotten." (Levi 2005,3)

_ Cover of the first edition of the Italian If This Is a Man (1947).

He therefore insisted on the extent of the massacre, the "greatest" in history and focused on the fact that it "practically [wiped] out the Jewish population of whole nations of Eastern Europe" (Ibid.). The following passage sealed the recent memory activist's public speech. By talking too much about the Lager, he said,

We risk being accused of victimism: at best of a gratuitous fascination with the macabre, at worst, of pure and simple mendacity, of an outrage to decency.

Is this silence justified? Should it be tolerated by those of us who are survivors? (Ibid.)

Us who are survivors: Levi, a modest, erased, shy, discreet man - as many terms as his close relations used to describe him - took a stand. And he proclaimed this "Us" 
Between testimony and memory, what place for Primo Levi? (continuation) as he had in If This Is a Man to speak in the name of deportees, both dead and alive. Signing on 11 July 1955 a contract for a revised edition of the book, his rewriting was greatly determined by this new stance and by the testimonial address which explicitly underlain it. During two years, always with other writing projects running in parallel, Levi reworked the argumentation just as much as the style of his first book and wove in what he had not been conscience of when he had just returned from such an improbable place, planted by the Nazis in Poland, where people died more than they lived.

In ten years his vision of the Nazi concentration camp terror system became clearer and his understanding sharper. The more he extended his knowledge through reading and publications on the subject, the more he was able of measuring the extent of the genocide of the Jews and the systematic nature of its programme. His discourse as a witness, in the public understanding of the term, was thus backed up by a knowledge which his experience alone could not have given him. The systematic killing of Jewish children (see Coquio \& Kalisky 2007) dawned to him with unprecedented brutality and, himself now the father of Lisa Lorenza and, soon, of Renzo, convinced him to add a certain number of passages on the children in the camps like Schlome (Hurbinek who in the end only appears in The Truce). The most striking of all remains the evocation of the young Emilia in the convoy which led them, end of February 1944, from Fossoli to Auschwitz. A paragraph of only ten lines mentions the three year old who could not, following SS law, survive the selection. Seeking to shock the reader who ought to be literally gripped by the anti-Semitic horror, he accumulates adjectives in favour of Emilia in a way which, for him, was completely unusual: "Curious, ambitious, cheerful, intelligent." His desire to move the reader was not limited to adding adjectives. He also brought an entire array of modifications to the second version. He thus mentioned and quoted more frequently Dante's Hell, a way for Levi of establishing echoes between the Divine Comedy, wellknown among Italian readers, and his own testimony, in an attempt to make it more accessible to his audience.

The opening to his readers is however not as obvious as in the following two passages of the soon-to-be canonical narrative. Firstly, in the version from 1947, Levi immediately began with his internment at the transit camp at Fossoli. Why does he mention the episode of his arrest and the question of his relation to the maquis, which are another story? In the 1958 version, he added two pages because it established a link, not with his earlier story, but with the current turn in memory which, in the 1950s, was carried by associations of members of the resistance, not of the Hebraic community, in which most Italian Jews who had returned from Nazi camps had met up. Secondly, after the second chapter he introduced the one titled "Initiation" - absent from the 1947 text - in which he portrayed a former Austro-Hungarian officer named Steinlauf, taken directly out of Joseph Roth's The Radetzki March. A discussion ensues on the necessity of adapting to the conditions at the camp in order to survive, concluding by returning to the interlocutor's argumentation who, in the eyes of the Piedmontese audience, remained emblematic of the rigidity of 
those who had historically dominated the country until the Risorgimento. This reworking is another call to meditate life under extreme conditions and a regime of terror whereas, fifteen years after the war, Italy was entering a period of prosperity.

I shall not dwell on the reception of this revised edition which, in fact, had to wait for the bookshop success of The Truce, retracing his return from Poland to Turin, for the strength of his composition and writing to be recognized. During the 1960s and 1970s, Primo Levi was at this point the witness we imagine. He went to schools, he was invited on television, he wrote in La Stampa, in the Corriere della Sera... chronicles in daily newspapers and magazines became a regular activity. He had a place at major papers. He participated in heated debates, for example, with Manganelli or with Paolo Volponi, ${ }^{7}$ or at the occasion of the controversial release of The Wrench which stirred "class" criticisms from the far-right. He publicly intervened against the Red Brigades, denounced the murder of Aldo Moro, the wave of Nazi-porn films, negationism, and in 1985 took a stand regarding the Historikerstreit. He recorded numerous television programmes. He participated in the conception of the monument at the Italian pavilion at Auschwitz, a project which took ten years to be completed, only seeing the day in 1972. His text became the official text of Italian deportation to Auschwitz. He also wrote the text for the plaque commemorating the deportation at the Turino Porta Nuova train station. In parallel, he pursued his writing and namely the reworking of If This Is a Man, inspiring a theatrical adaptation staged in Turin in 1966, versions for schools, but also, finally, a collection of essays in which criticism of the or of his position as a witness became a keystone. So I wish to conclude with this question, which casts a sombre light on his rereading, forty years later, of his testimonial experience, and on the reception during the 1980s of the voice of witnesses (he committed suicide on 11 April 1987).

\section{TESTIMONIAL FATIGUE AND CRITICISM}

A blend of the 1970s and of his depression, the following decade was, for Levi, characterized by the collapse of a testimonial function.

So, I have become a "professional survivor", nearly a mercenary... (laughs) My experience of that time has deeply changed. It has been altered by later reflections, conversations, just like the one I am having with you now. I have granted a great deal of interviews, and all of this sits between authentic experience and today [...] All of this raises a great barrier. (Levi 1998, 252; translation SV)

Living with such memory became a challenge for him and evolved into a deep uneasiness. For the survivor (the one who exited the camp) to pull the witness (the one who lived in the camp) toward the light of existence caused Levi a profound dilemma. While sharing his experience, the survivor was drawn away. Levi realized that whenever he found himself in a situation to bear witness, words did not assist him as they previously had. They no longer served as a mediation which bound the
(7) Primo Levi was involved in a heated debate with writer Giorgio

Manganelli who attacked in the Corriere della Sera dated

from 3 January 1977 his article

'On obscure writing', published in La Stampa a few days earlier. 


\section{DOSSIER}

Between testimony and memory, what place for Primo Levi?

(continuation)
_ Theatre adaptation of If This Is a Man, staged for the first time on 18 November 1966 at the Carignano theatre in Turin. witness to the survivor. Words lost their power to refer to reality (lived reality, reality of experience, of what had happened).

I do not readily go to schools anymore. On the one hand, I admit, I am tired of repeatedly hearing the same questions asked. On the other hand, I have the feeling that my language has grown insufficient, that I speak another language. And also, I must admit that I was cut to the quick by one of my latest experiences in a school, where two children, two brothers, asked me in an irrefutable tone: "Why do you still come tell us your story, forty years on, after Vietnam, after Stalin's camps, Korea, after all that... why?’ And I must say that I remained at a loss for words, speechless, backed into a corner, into my condition as a survivor at all cost. (Levi 1994, 37; translation SV)

His friend Edith Bruck had a similar experience. After having written about ten books, autobiographical and testimonial narratives, poetry, tainted by themes of exile, solitude, Jewishness and meditating her own experience, she published Signora Auschwitz borrowing the expression by which a student used to call her.

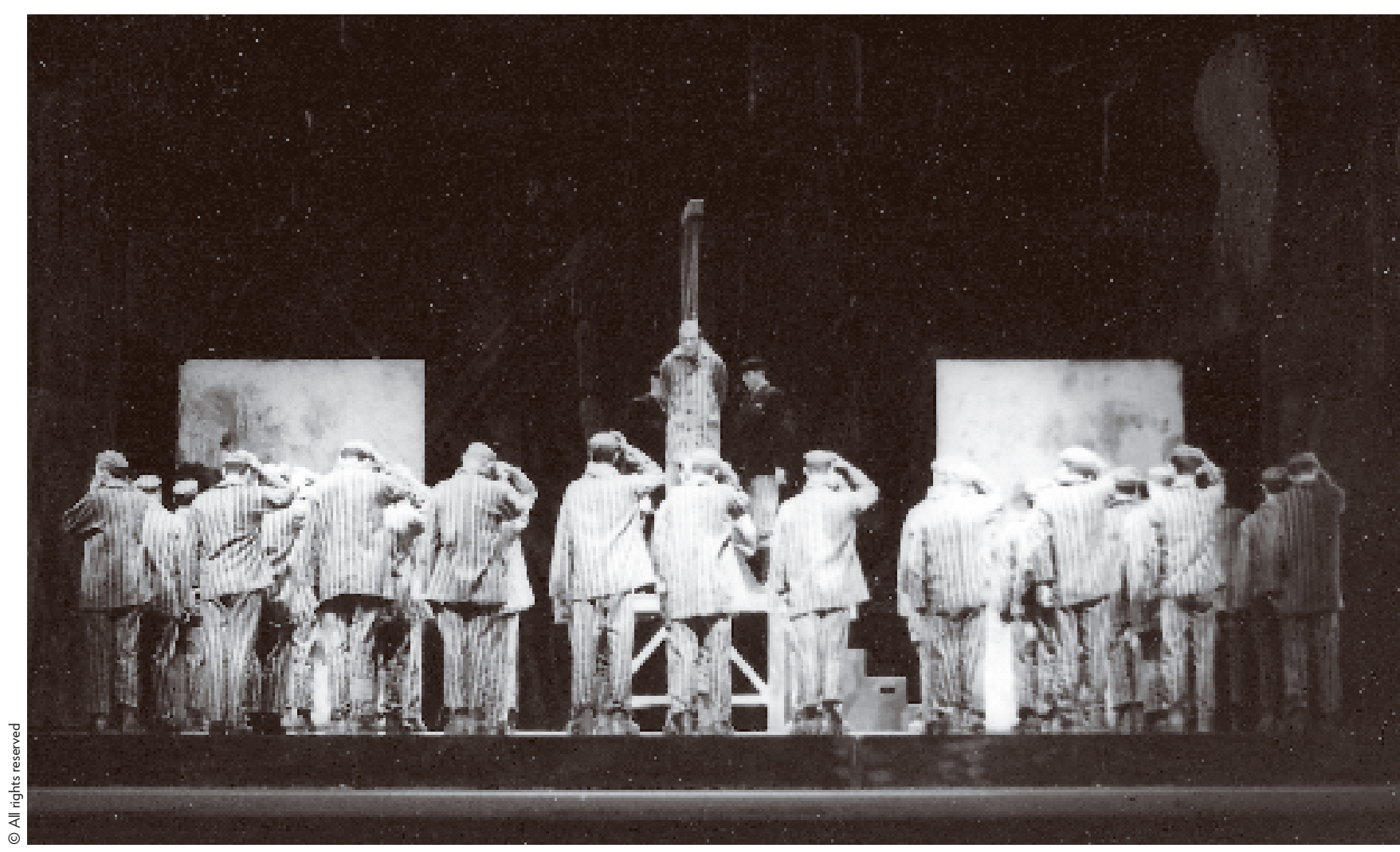


From the start, Levi laid down his strongest cards: had witnesses correctly fulfilled their duty? Had the reception among young people not been misrepresented? He therefore addressed the community of survivors by convoking this us so often present in If This Is a Man. "Have we - we who have returned - been able to understand and make others understand our experiences?” (Levi 1988, 36) This attack was not insignificant and filled the two first pages of the essay titled "The Grey Zone" in the collection I sommersi e $i$ salviti, published in 1985 (English translation 1988). "We also tend to simplify history": three times he repeated "simplify", "simplification". One had not yet critically measured the statement which Levi held a mirror up to, when, precisely in the mid-1980s, the grand project of recording testimonies was launched.

Witnesses at the time did not hear him and, in a way, the fact that Levi was delegated by a number of them to speak in their place, did not help them become aware. Levi stressed that one cannot understand such complexity in terms of friend and enemy.

This is certainly the reason for the enormous popularity of spectator sports, such as soccer, baseball, and boxing: the contenders are two teams or two individuals, clearly distinct and identifiable, and at the end of the match there are vanquished and victors. (Levi 1988, 37)

In this respect, he called out to the young people who, in his eyes, felt the need "to separate evil from good, to be able to take sides", who wanted "here the righteous, over there the reprobates". They "above all demand clarity, a sharp cut". The mentality of the public was also characterized by stereotypes and this greatly disappointed him: "their experience of the world being meagre, they do not like ambiguity" (Ibid.).

Levi knew that the testimonies of deportees, through having convoked models and stereotypes, had erased the grey zone and, thereby, interfered with the understanding of the concentration camp universe by simplifying it. This is the paradox of a transmission which, in order to make one's object accessible, denatures it by omitting parts of its complexity. He heavily moralized his own testimony and began bearing witness a long time before exploring this grey zone himself. His words did not spare him and they certainly even smacked him at times, he who tried to deliver a "tempered" vision as he puts it in Se questo è un uomo, and who found himself making this grey zone into a combative notion against testimonies.

$$
\text { 棌 }
$$

The various rewritings of If This Is a Man until his final essay The Drowned and the Saved retrace the expectation of a man who was never satisfied with his own position, nor with the comfort it could have given him - the recognition and honour devoted to a great writer and a major witness whose name circulated among potential Nobel Prize holders. Yet, Primo Levi did not hesitate to unknit his own 
Between testimony and memory, what place for Primo Levi? (continuation) legends in order to respond to the imperious necessity to think, not only to reflect the experience of a system of terror whose end was to abolish thought and culture before the destruction of humans, but also the unstable and relentless condition of the one who found himself between testimony and memory.

\section{WORKS CITED}

- Antelme, Robert, The Human Race, translated from the French by Jeffrey Haight \& Annie Mahler, Marlboro Press, 1988.

- Bertilotti, Paola, 'La notion de déporté en Italie, de 1945 à nos jours. Droit, politiques de la mémoire et mémoire concurrentes', in Tal Bruttmann, Laurent Joly \& Annette Wieviorka (eds.), Qu'est-ce qu'un déporté? Histoire et mémoires des déportations de la Seconde Guerre mondiale, Paris: CNRS éditions, 2009, 377-402.

- Cayrol, Jean, 'Pour un romanesque lazaréen' (1949), in Lazare parmi nous, Paris: Le Seuil, 1950, 69-106.

- Coquio, Catherine \& Aurélia Kalisky (eds.), L'Enfant et le génocide. Témoignages sur l'enfance pendant la Shoah, Paris: Robert Laffont, 2007.

- Crainz, Guido, Autobiografia di una Repubblica. Le radici dell'Italia attuale, Rome: Donzelli, 2009.

- Kertész, Imre, 'Holocaust als Kultur' (1992), in Eine Gedankenlänge Stille, während das Erschiessungskommando neu lädt, Hamburg: Rowohlt, 1999, 54-69.

- Levi, Primo, If This is a Man, translated by Stuart Woolf, Orion Press, 1959.

-, 'The Grey Zone', in The Drowned and the Saved, translated from the Italian by Raymond Rosenthal, London: Michael Jospeph, 1988, 36-69.

-, The Sixth Day and Other Tales, translated from the Italian by Raymond Rosenthal, London: Michael Joseph, 1990.

-, Le devoir de mémoire (1983), interview with Anna Bravo and Frederico Cereja, Paris: Mille et une nuits, 1994.

_, 'Les Mnémagogues' (1946), in Histoires naturelles (1966), Paris: Gallimard, 1994, 11-21.

-, Conversations et entretiens 1963-1987, translated from the Italian and English by T. Laget, Paris: Robert Laffont, 1998

-, The Black Hole of Auschwitz, translated from the Italian by Sharon Wood, Cambridge: Polity, 2005.

_, Auschwitz Report, translated from the Italian by Judith Woolf, edited by Robert Gordon, London: Verso, 2006.

- Lowe, Keith, Savage Continent: Europe in the Aftermath of World War II, London: Viking, 2012.

- Malabaila, Damiano (Primo Levi), Storie naturali, Turin: Einaudi, 1966.

- Pavone, Claudio, Alle origini della Repubblica. Scritti su fascismo, antifascismo e continuita, Turin: Bollati Boringhieri, 1995. 